\title{
DROGĄ OKRĘŻNĄ Z ZIEMI WŁOSKIEJ DO POLSKI. PRAKTYCZNE ASPEKTY ZAWODU TŁUMACZA PRZYSIĘGŁEGO WE WŁOSZECH I PROCEDURA UZNAWANIA JEGO KWALIFIKACJI W POLSCE
}

DOl: http://dx.doi.org/10.12775/RP.2015.010

Zarys treści: Celem niniejszego artykułu jest gruntowne przedstawienie praktycznych aspektów ścieżki kariery zawodowej tłumacza przysięgłego we Włoszech oraz omówienie rozporządzenia określającego zasady uznawania jego kwalifikacji w Polsce. Temat dotyczący statusu tłumacza przysięgłego we Włoszech nie został dotychczas wystarczająco zbadany ${ }^{1}$, dlatego w niniejszym artykule podjęto próbę jego obszerniejszej i wnikliwszej analizy.

Słowa kluczowe: tłumacz przysięgły, kwalifikacje zawodowe, status tłumacza

W. konywanie zawodu tłumacza przysięgłego w Polsce reguluje Ustawa zawodzie tłumacza przysięgłego z dnia 25 listopada 2004 roku, która obowiązuje od 27 stycznia 2005 roku. Kandydaci na tłumacza przysięgłego nabywają prawo do wykonywania zawodu dopiero po zdaniu egzaminu przygotowanego przez Ministerstwo Sprawiedliwości. 30 listopada 2010 roku weszło w życie przełomowe rozporządzenie, na podstawie którego tłumacze, którzy uzyskali status przysięgłego w jednym z państw członkowskich Unii Europejskiej, mogą ubiegać się o nostryfikację ich tytułu zawodowego w Pol-

${ }^{1} \mathrm{O}$ zawodzie tłumacza przysięgłego we Włoszech piszą jedynie K. Biernacka-Licznar (2011: 165-182) oraz skrótowo A. Kubacki (2012: 96-98). 
sce. Niniejszy artykuł ma na celu przybliżenie zawodu tłumacza przysięgłego we Włoszech, przedstawienie jego ścieżki kariery oraz krótkie skomentowanie rozporządzenia ministra sprawiedliwości, które pozwala tłumaczowi na ubieganie się o uznanie kwalifikacji w Polsce.

1 lipca 2011 roku w związku z Ustawą z dnia 25 marca 2011 r. o ograniczaniu barier administracyjnych dla obywateli i przedsiębiorców (Dz.U. z 25 maja 2011 r. Nr 106 poz. 622) weszły w życie nowe przepisy, które wprowadzają kilka istotnych zmian w obowiązującej obecnie Ustawie o zawodzie tłumacza przysięgłego ${ }^{2}$.

Jak pisze na swoim blogu ${ }^{3}$ Renata Świgońska, prawnik i tłumacz przysięgły, obecnie wystarczy uzyskanie tytułu magistra jakiegokolwiek kierunku, aby przystąpić do egzaminu na tłumacza przysięgłego. Przed nowelizacją tylko magister filologii lub osoba $\mathrm{z}$ wykształceniem wyższym magisterskim, która odbyła studia podyplomowe w zakresie tłumaczenia, mogła zostać tłumaczem przysięgłym. Zostaje zniesiony roczny okres karencji w przypadku niezdania egzaminu. Osoby zainteresowane ponownym zdawaniem egzaminu będą mogły do niego przystąpić w najbliższym możliwym terminie ${ }^{4}$. Do tej pory w razie niedostatecznego wyniku egzaminu kandydat na tłumacza przysięgłego mógł przystąpić ponownie do egzaminu nie wcześniej niż po upływie roku od daty poprzedniego egzaminu. Dotychczas tłumacz po zdaniu egzaminu kierował wniosek do ministra sprawiedliwości o wpisanie go na listę tłumaczy przysięgłych, zgodnie bowiem $\mathrm{z}$ ustawą tłumacz był wpisywany na listę wyłącznie na swój wniosek. Po nowelizacji wpis na ministerialną listę tłumaczy przysięgłych będzie się odbywał z urzędu, a nie na wniosek. To istotna i pozytywna zmiana, ponieważ zdarzało się, że kandydaci po zdaniu egzaminu czekali nawet pół roku na wpis na listę i nie mogli w tym czasie wykonywać zawodu tłumacza przysięgłego 5 .

Jednak najważniejsze zmiany dotyczą uznania kwalifikacji zdobytych za granicą, które długo nie dawały uprawnień do wykonywania tego zawodu w Polsce. W czasie prac Ministerstwa Sprawiedliwości pojawiło się rozporządzenie $\mathrm{w}$ sprawie stażu adaptacyjnego i testu umiejętności w toku postępo-

${ }^{2}$ Ustawa z dnia 25 listopada 2004 r. o zawodzie tłumacza przysięgłego (Dz.U. Nr 273, poz. 2702 z późn. zm.).

${ }^{3}$ http://www.tlumaczeniaprawnicze.com.pl/2011/06/08/zmiany-w-ustawie-o-zawodzietlumacza-przysieglego/ (dostęp: 7 grudnia 2013 r.).

${ }^{4}$ Ustawa z dnia 25 marca $2011 \mathrm{r}$ o ograniczaniu barier administracyjnych dla obywateli i przedsiębiorców (Dz.U. Nr 106, poz. 622 z późn. zm.).

${ }^{5} \mathrm{http}: / /$ www.tlumaczeniaprawnicze.com.pl/2011/06/08/zmiany-w-ustawie-o-zawodzietlumacza-przysieglego/ (dostęp: 7 grudnia 2013 r.). 
wania o uznanie kwalifikacji do wykonywania zawodu tłumacza przysięgłego (projekt z dnia 17 sierpnia 2010 r.). Weszło ono w życie z 30 listopada 2010 r. Na jego podstawie osoby, które zdobyły kwalifikacje zawodowe w jednym z państw członkowskich Unii Europejskiej będą zobowiązane do odbycia tzw. stażu adaptacyjnego, opiekunem którego powinien być tłumacz przysięgły, wyznaczony przez Ministerstwo Sprawiedliwości, wykonujący czynności nieprzerwanie minimum 3 lata, lub przejścia „testu umiejętności”, składającego się z dwóch części: pisemnej - trwającej 120 minut, sprowadzającej się do przetłumaczenia jednego tekstu $\mathrm{z}$ języka polskiego na język obcy i jednego tekstu z języka obcego na polski, oraz ustnej - polegającej na tłumaczeniu konsekutywnym i a vista ${ }^{6}$.

Dzięki temu rozporządzeniu tłumacz może uzyskać kwalifikacje $w$ innych państwach członkowskich Unii Europejskiej, aby później, po odbyciu stażu adaptacyjnego lub przejściu testu umiejętności, jego kwalifikacje zostały uznane w Polsce. Włochy są właśnie jednym z tych państw członkowskich, w którym tłumacz mógłby uzyskać status przysięgłego, aby potem ubiegać się o nostryfikację jego tytułu zawodowego. Przyjrzyjmy się więc teraz statusowi, kształceniu, warsztatowi i odpowiedzialności tłumacza przysięgłego na Półwyspie Apenińskim.

Na początku warto zauważyć, że zawód tłumacza przysięgłego we Włoszech nie przynależy do żadnego samorządu zawodowego; tłumacz nie jest więc osobą zaufania publicznego. Brakuje także ustawy regulującej warunki nabywania prawa do wykonywania zawodu tłumacza przysięgłego (Biernacka-Licznar 2011: 171). Nie obowiązuje żaden egzamin potwierdzający kwalifikacje zawodowe ani też rejestr krajowy lub regionalny, w którym tłumacz mógłby się zarejestrować, żeby wykonywać swój zawód. Zatem tłumacz przysięgły we Włoszech nie jest rozumiany tak samo jak w innych krajach Europy (w tym w Polsce), w których - aby uzyskać taki tytuł - należy zdać egzamin państwowy, upoważniający do wykonywania zawodu i sporządzania tłumaczeń przysięgłych we własnym zakresie, tzn. bez konieczności stawiania się w sądzie w celu ich uwierzytelniania, co wiąże się ze stratą czasu i kosztami. W rzeczywistości osoba asystująca sędziemu podczas wykonywania czynności, w przypadku których nie ma on niezbędnych narzędzi poznawczych (tu: znajomości języków obcych, ale również wiedzy z zakresu medycyny, księgowości, agronomii oraz wielu innych), zdefiniowana jest przez normy prawne

${ }^{6}$ Rozporządzenie Ministra Sprawiedliwości z dnia 9 listopada 2010 r. w sprawie stażu adaptacyjnego i testu umiejętności w toku postępowania o uznanie kwalifikacji do wykonywania zawodu tłumacza przysięgłego (Dz.U. Nr 218, poz. 1441). 
w języku włoskim jako CTU (consulente tecnico d’ufficio), czyli doradca techniczny lub biegły, zależnie od sytuacji. W dalszej części artykułu porównamy różnice pomiędzy obiema funkcjami.

We Włoszech tłumaczenia kolokwialnie nazywane „przysięgłymi” (traduzioni giurate) definiuje się prawnie tłumaczeniami poświadczonymi (traduzioni asseverate). W przeciwieństwie do polskich standardów, to nie tłumacz jest „przysięgły” (nie można zatem mówić o „tłumaczu poświadczonym"), ale każde jego tłumaczenie. Tłumacz - w zakresie swoich obowiązków - może wykonywać zadania w sposób bezpośredni, na sali rozpraw, a więc pod przysięgą (tłumaczenia ustne, interpretariato) oraz w domu lub w biurze (tłumaczenia pisemne, traduzioni, dostarczane później do sądu i podpisywane w obecności urzędnika $\mathrm{z}$ kancelarii sądu właściwego dla danego miejsca zamieszkania). Ten drugi przypadek przewiduje, że tłumacz dostarcza osobiście do sądu tekst oryginalny wraz z tłumaczeniem, znaczkami opłaty skarbowej oraz podpisanym zleceniem, zawierającym dane osobowe, typologię tekstu, języki robocze oraz daty rozpoczęcia i zakończenia pracy. Tekst źródłowy (oryginał lub odpis) oraz jego tłumaczenie muszą stanowić jedną nierozerwalną całość. Ostatnią stroną jest tzw. protokół poświadczenia wydany przez sąd. Znaczki skarbowe umieszczone są na co czwartej stronie tłumaczenia i na protokole. Ważne jest również to, że tłumacz nie może złożyć podpisu pod tłumaczeniem, zanim nie przedstawi go $\mathrm{w}$ sądzie. $\mathrm{W}$ przeciwnym wypadku będzie zobowiązany do ponownego sporządzenia dokumentu. Taka sama procedura może odbyć się nie tylko w sądzie, ale również w obecności notariusza (jednak pociąga to za sobą wyższe koszty) lub teoretycznie przed jakimkolwiek urzędnikiem państwowym; jednak w praktyce jedyną odpowiednią siedzibą jest sąd. Tłumaczenia są więc wykonywane pod przysięgą, co oznacza, że tłumacz oświadcza w obecności urzędnika sądu rzetelne sporządzenie tłumaczenia. Zaprzysiężenie jest zatem przyjęciem odpowiedzialności przez tłumacza. Należy w tym miejscu podkreślić, że nawet taka forma tłumaczenia nie gwarantuje wysokiej jakości jego wykonania, ponieważ sąd nie weryfikuje tłumaczenia, ograniczając się jedynie do uznania złożonej przysięgi.

Uwierzytelnienie tłumaczenia (asseverazione) niesie ze sobą więc konieczność udania się do sądu właściwego dla miejsca zamieszkania tłumacza przysięgłego. Zgodnie z okólnikiem Rady Ministrów z 15 grudnia 1980 r.,

[...] non esistendo in Italia la figura professionale del traduttore ufficiale, viene di norma richiesta dai Paesi esteri la traduzione da parte di traduttori giurati iscritti all'albo dei Consulenti Tecnici d'Ufficio (CTU) esistenti presso ogni Tribunale. Poiché 
la decisione di accettare o meno una traduzione giurata/ufficiale/asseverata è del Paese dove il documento deve essere presentato, sarà quindi necessario accertarsi caso per caso se viene accettata anche una traduzione effettuata da altri soggetti. [omissis] Per traduttori ufficiali devono intendersi tutti coloro in grado di fornire una traduzione 'ufficiale' di un testo straniero, e cioè quei soggetti che, particolarmente competenti in lingue straniere, sono in grado di procedere ad una fedele versione del testo originario fornendo ad essa il crisma della 'ufficialità' in forza di una preesistente abilitazione (iscrizione agli albi) o mediante successive procedure (es. giuramento)

[...] ze względu na brak we Włoszech stanowiska tłumacza urzędowego, inne Państwa zasadniczo wymagają tłumaczenia wykonanego przez tłumaczy przysięgłych wpisanych do rejestru Doradców Technicznych z Urzędu (CTU), który znajduje się w każdym sądzie. Ponieważ decyzja o zaakceptowaniu lub niezaakceptowaniu tłumaczenia przysięgłego (urzędowego lub uwierzytelnionego) zależy od kraju, w którym dany dokument będzie przedstawiony, konieczne jest upewnienie się w każdym przypadku z osobna, czy akceptowane jest także tłumaczenie wykonane przez inne podmioty [omissis]. Za tłumaczy urzędowych należy uważać wszystkich tych, którzy są w stanie dostarczyć tłumaczenie „urzędowe” tekstu z języka obcego, to znaczy te podmioty, które mając szczególne kompetencje z zakresu języków obcych, są w stanie wykonać wierny przekład tekstu oryginalnego i opatrzyć go odpowiednimi pieczęciami na podstawie otrzymanego wcześniej upoważnienia (wpis do rejestrów) lub przez inne procedury (np. zaprzysiężenie) $)^{7}$.

Dlaczego więc używamy określenia „tłumacz przysięgły” (traduttore giurato)? Najprawdopodobniej wynika to z faktu, że tłumacz - zanim wykona swoje zadanie doradcze - „przysięga wykonać sumiennie i wiernie powierzone mu zadanie, w celu pomocy w poznaniu prawdy” („giura di adempiere bene e fedelmente al compito affidatogli, al solo scopo di far conoscere la verità”) ${ }^{8}$. Zgodnie z definicją, której autorem jest Piero Calamandrei ${ }^{9}$, „CTU jest lupą sędziego” (,il CTU è l'occhiale del giudice”) (Calamandrei 1943: 167, tłumaczenie własne), osobą, która pomaga sędziemu zobaczyć więcej, niż pozwala mu jego wiedza. Interesująca okazać się może wzmianka na temat tego, jak powstała i rozwinęła się osoba pomocnika sędziego.

7 Tłumaczenie własne.

${ }^{8}$ Art. 193 Kodeksu postępowania cywilnego (Codice di procedura civile) - tłumaczenie własne.

${ }^{9}$ Włoski prawnik, polityk i pisarz (1989-1956); jeden z autorów Kodeksu postępowania cywilnego z 1942 r., który obecnie częściowo jeszcze obowiązuje we Włoszech. 
Należy zacząć od Kodeksu postępowania cywilnego (Codice di procedura civile) z 1865 r., ustanawiającego m.in. normy dotyczące opinii biegłego, rozumianej jako rodzaj świadectwa technicznego. Biegły mógł zostać powołany przez strony i wezwany do stawienia się, aby złożyć przysięgę. Nie wymagano wtedy żadnych szczególnych umiejętności. Biegły mógł być nawet analfabetą. Kodeks z roku 1865 postrzega opinię biegłego jako zeznanie świadka, z tą różnicą, że opinia biegłego określa fakty stałe, podczas gdy zeznanie świadka określa fakty przejściowe.

Dekret królewski (Regio Decreto) z 26 lutego 1928 r., a następnie Dekret królewski z 21 maja 1934 r. nadały sędziemu uprawnienia do powoływania jednego lub więcej doradców technicznych, którzy mieli mu asystować podczas przeprowadzenia postępowania lub podczas całego sporu.

Wraz z wejściem w życie Kodeksu z 1940 r. nastąpiła radykalna zmiana $\mathrm{w}$ rozumieniu biegłego, polegająca na uznaniu nowej typologii wsparcia udzielanego sędziemu oraz na przyjęciu przez CTU innej roli. Następuje przejście od tworzenia aktu (opinii biegłego) do współpracy opierającej się na zaufaniu. Doradca techniczny ma w istocie szczególne kompetencje i jest niezależnym od stron pomocnikiem sędziego.

Istnieją dwa typy takich doradców. Wyróżnia się CTU w ścisłym tego słowa znaczeniu, którego zadanie polega na ustalaniu i ocenie faktów za pomocą narzędzi naukowych, oraz zwykłego eksperta lub rzeczoznawcę, który wspomaga sędziego podczas przeprowadzania danych czynności, przy wykorzystaniu własnych szczególnych kompetencji. Do tej drugiej kategorii zalicza się tłumaczy. Jednakże w praktyce zawsze używa się określenia CTU.

W ten sposób dotarliśmy do sedna sprawy. Gdy pracujemy dla sądu, to w jakim charakterze tam pracujemy? Kim jest dziś CTU? Kim jest dziś biegły? Kim jest pomocnik Policji Sądowej $\left(\mathrm{PG}^{10}\right)$ ? Przede wszystkim należy rozróżnić proces cywilny od procesu karnego. Podstawowym przepisem, który opisuje doradcę technicznego w procesie cywilnym, jest art. 61 Kodeksu postępowania cywilnego mówiący o „Consulente tecnico” [doradca techniczny]. Kodeks w pierwszym ustępie stanowi, że:

Quando è necessario, il giudice può farsi assistere, per il compimento dei singoli atti o per tutto il processo, da uno o più consulenti di particolare competenza tecnica.

${ }^{10}$ Skrót pochodzi od włoskiej Policji Sądowej (Polizia Giudiziaria), jednak zakres jej kompetencji nie ma nic wspólnego z zakresem kompetencji polskiej Policji Sądowej. W warunkach polskich byłyby to raczej sekcje bądź wydziały kryminalne policji. 
Gdy zachodzi konieczność, sędzia w celu przeprowadzenia poszczególnych czynności lub podczas całego procesu, może skorzystać z pomocy jednego lub kilku biegłych mających szczególne kompetencje techniczne [tłumaczenie własne].

Zagadnienia proceduralne dotyczące powołania CTU i powierzania mu obowiązków są uregulowane przez art. 191 i kolejne Kodeksu postępowania cywilnego. Art. 191 ustęp 1 Kodeksu postępowania cywilnego „Nomina del consulente tecnico" [Powoływanie doradcy technicznego] stanowi, że

Nei casi di cui agli articoli 61 e seguenti il giudice istruttore [omissis], nomina un consulente tecnico e fissa l'udienza nella quale questi deve comparire.

W przypadkach, o których mowa w art. 61 i kolejnych sędzia śledczy [omissis], powołuje doradcę technicznego i ustala datę rozprawy, na której doradca musi się stawić [tłumaczenie własne].

Art. 193 Kodeksu postępowania cywilnego „Giuramento del consulente” [Zaprzysiężenie doradcy] stanowi:

All'udienza di comparizione il giudice istruttore ricorda al consulente l'importanza delle funzioni che è chiamato ad adempiere, e ne riceve giuramento di bene e fedelmente adempiere le funzioni affidategli al solo scopo di fare conoscere ai giudici la verità.

Podczas rozprawy sędzia śledczy przypomina doradcy powagę funkcji, którą tenże będzie spełniać, po czym następuje przysięga wykonania sumiennie i wiernie powierzonego mu zadania, w celu pomocy sędziom w poznaniu prawdy [tłumaczenie własne].

Szczegółowa zasada odnosząca się do tłumacza ustnego opisana jest w art. 122 Kodeksu postępowania cywilnego „Uso della lingua italiana - Nomina dell’interprete" [Posługiwanie się językiem włoskim - Powołanie tłumacza ustnego].

In tutto il processo è prescritto l'uso della lingua italiana. Quando deve essere sentito chi non conosce la lingua italiana, il giudice può nominare un interprete. Questi, prima di esercitare le sue funzioni, presta giuramento davanti al giudice di adempiere fedelmente il suo ufficio.

Podczas całego postępowania obowiązkowym językiem jest język włoski. Do przesłuchania osoby niewładającej językiem włoskim sędzia może powołać tłu- 
macza ustnego. Tłumacz ten, zanim przystąpi do wykonywania powierzonego mu zadania, ślubuje, że będzie wiernie wykonywać swoje obowiązki [tłumaczenie własne].

Szczegółowa zasada odnosząca się do tłumacza pisemnego opisana jest w art. 123 Kodeksu postępowania cywilnego „Nomina del traduttore” [Powołanie tłumacza pisemnego].

Quando occorre procedere all'esame di documenti che non sono scritti in lingua italiana, il giudice può nominare un traduttore, il quale presta giuramento a norma dell'articolo precedente.

Gdy zachodzi konieczność zbadania dokumentów, które nie zostały sporządzone w języku włoskim, sędzia może powołać tłumacza pisemnego, który składa przysięgę zgodnie z poprzednim artykułem [tłumaczenie własne].

W zakresie postępowania karnego pierwsze uściślenie terminologiczne związane jest z różnicą pomiędzy określeniami „biegły” a „pomocnik Policji Sądowej”. Ostatni termin jest synonimem „biegłego” na etapie postępowania przygotowawczego, tzn. przed rozpoczęciem ewentualnego procesu, podczas gdy nie można mówić o sytuacji odwrotnej. Nie można mówić o „pomocniku Policji Sądowej”, mając na myśli „biegłego”, którego wystąpienia żąda sędzia podczas przebiegu procesu, w zakresie, w którym Policja Sądowa wyczerpała swe działania związane jedynie z fazą przygotowawczą. Opinia biegłego jest czynnością, która może być wymagana zarówno podczas fazy przygotowawczej, jak i przez sędziego podczas procesu, i jest ona regulowana przez art. 220 i kolejne Kodeksu postępowania karnego (Codice di procedura penale).

Art. 220 Kodeksu postępowania karnego ustęp 1 stanowi:

Oggetto della perizia: La perizia è ammessa quando occorre svolgere indagini o acquisire dati o valutazioni che richiedono specifiche competenze tecniche, scientifiche $o$ artistiche.

Przedmiot opinii biegłego: Opinia biegłego jest dopuszczalna, gdy zachodzi konieczność przeprowadzenia dochodzenia, zdobycia danych lub oceny, które wymagają konkretnych kompetencji technicznych, naukowych lub artystycznych [tłumaczenie własne]. 
Art. 225 Kodeksu postępowania karnego ustęp 1 stanowi:

Nomina del consulente tecnico: Disposta la perizia, il pubblico ministero e le parti private hanno facoltà di nominare i propri consulenti tecnici in numero non superiore, per ciascuna parte, a quello dei periti.

Powołanie doradcy technicznego: Po zarządzeniu sporządzenia opinii biegłego, prokurator oraz podmioty prywatne mają prawo do powołania własnych doradców technicznych w liczbie nie większej, dla każdej strony, niż liczba biegłych [tłumaczenie własne].

\section{Art. 226 Kodeksu postępowania karnego ustęp 1 stanowi:}

Conferimento dell'incarico: Il giudice, accertate le generalità del perito, [omissis], lo avverte degli obblighi e delle responsabilità previste dalla legge penale e lo invita a rendere la seguente dichiarazione: consapevole della responsabilità morale e giuridica che assumo nello svolgimento dell'incarico, mi impegno ad adempiere al mio ufficio senza altro scopo che quello di far conoscere la verità e a mantenere il segreto su tutte le operazioni peritali.

Przypisanie obowiązków: Sędzia, po sprawdzeniu danych biegłego, [omissis], uprzedza go odnośnie do jego obowiązków oraz odpowiedzialności przewidzianych w prawie karnym oraz prosi o złożenie następującego oświadczenia: świadom odpowiedzialności moralnej oraz prawnej, którą biorę na siebie podczas wykonywania zadania, podejmuję się pełnić mój urząd, nie dążąc do innego celu poza doprowadzeniem do poznania prawdy i zachowania w tajemnicy wszelkich przeprowadzonych ekspertyz [tłumaczenie własne].

Jakie kroki musi więc przedsięwziąć tłumacz pisemny (traduttore) lub ustny (interprete), który chciałby pełnić funkcję CTU? Przede wszystkim musi wpisać się do odpowiednich rejestrów sądowych. Następnie w celu przypisania obowiązków będzie mógł być wezwany przez sędziego lub prokuratora, którzy pozyskują nazwiska tłumaczy $\mathrm{z}$ owych rejestrów ${ }^{11}$. Z dyskusji prowadzonych na forach internetowych z wieloma „tłumaczami przysię-

${ }^{11}$ Dokładny opis postępowania - począwszy od złożenia podania w celu wpisania się do rejestru CTU, poprzez przypisanie obowiązków oraz przeprowadzenie konsultacji lub opinii biegłego, aż po złożenie podania o wynagrodzenie oraz jego pobranie - dostępny jest na stronie www.ferrotraduzioni.it pod hasłem „Vademecum del traduttore giurato” [Vademecum tłumacza przysięgłego]. 
głymi” działającymi we Włoszech wynika, że istnieją pewne różnice, czasem wręcz podstawowe, pomiędzy poszczególnymi sądami, jeśli chodzi o wymagania w stosunku do tłumaczy, którzy pragną wpisać się do rejestru, a przede wszystkim pomiędzy procedurami dotyczącymi uwierzytelnienia tłumaczeń.

Ponieważ nie istnieje jedna obowiązująca procedura dotycząca wpisu do rejestru, należy zwrócić się do sądu właściwego dla miejsca zamieszkania. W celu udokumentowania własnego doświadczenia i profesjonalizmu w branży tłumaczeniowej konieczne jest przedstawienie dokumentacji, oczywiście opieczętowanej, wraz z uiszczeniem opłaty wpisowej, która nie musi być odnawiana co roku (kwota wynosi od 150 do 200 euro). W niektórych sądach wymagany jest też wpis do rejestru tłumaczy (Albo dei Traduttori ed Interpreti) przy Izbie Handlowej (Camera di Commercio) danego powiatu, gdzie corocznie należy przelać kwotę około 150 euro. W tym przypadku trzeba również podejść do egzaminu na tłumacza w jednej z Izb. Wniosek o dopuszczenie do egzaminu trzeba złożyć w odpowiednim biurze Izby Handlowej właściwej dla miejsca zamieszkania. Sprawdzenie kompetencji translatorskich odbywa się w ustalonych wcześniej odstępach czasu, a osoby zapisane zostają wezwane na najbliższy termin ${ }^{12}$. Sam egzamin nie jest trudny: zazwyczaj polega na krótkiej rozmowie $\mathrm{w}$ języku obcym ${ }^{13}$ i tłumaczeniu artykułów z prasy lub czasopism traktujących o bardzo różnej tematyce ${ }^{14}$.

Każdy sąd ma rejestr doradców technicznych, który przechowywany jest przez prezesa sądu, a wszystkie decyzje dotyczące wpisu do rejestru są uchwalane przez komitet, któremu on sam przewodniczy. Komitet składa się z prokuratora oraz przedstawiciela powołanego przez radę samorządu zawodowego, do którego kandydat na CTU należy. Kandydat składa do biura doradców technicznych (Ufficio CTU) sądu właściwego dla miejsca zamieszkania wniosek o wpis do rejestru doradców technicznych (Albo dei Consulenti Tecnici d'Ufficio) wraz ze swoim udokumentowanym doświadczeniem zawodowym, zgodnie z przepisami wykonawczymi wydanymi na podstawie art. 13-24 61-64 i 191-201 Kodeksu postępowania cywilnego. Biuro CTU jest odpowiedzialne za prowadzenie rejestru doradców technicznych pozostających do dyspozycji prokuratury, za stawianie zarzutów natury dyscyplinarnej i nakładanie sankcji oraz za okresowy przegląd kontrolny rejestru w celu

${ }^{12}$ http://www.e-schooloftranslation.org/professione-traduttore/traduzioni-giurate\#sthash. RqYVKW0J.dpuf (dostęp: 7 grudnia 2013 r.).

${ }^{13} \mathrm{http} / / /$ www.proz.com/forum/italian/11943-come_diventare_traduttore_giurato.html (dostęp: 7 grudnia 2013 r.).

${ }^{14} \mathrm{http}: / /$ glottovolante.blogspot.com/2011/11/traduttori-registrati-presso-la-camera.html (dostęp: 7 grudnia 2013 r.). 
sprawdzenia ważności wymogów (szczególne kompetencje, nieskazitelna postawa moralna, zameldowanie itd.) niezbędnych do wpisu.

Dokumenty wymagane do uzyskania wpisu do rejestru doradców technicznych CTU (do złożenia np. w Biurze CTU w Sądzie Rejonowym (Tribunale Ordinario) przy via Lepanto 4 , Roma ${ }^{15}$ ) to:

- wniosek o wpis do rejestru, po uprzednim wniesieniu opłat skarbowych, skierowany do prezesa sądu, ze wskazaniem obszaru specjalizacji (nie więcej niż cztery specjalizacje; wykaz do wglądu w biurze CTU);

- kserokopia aktualnego dokumentu tożsamości (kandydat zobowiązany jest mieć miejsce zamieszkania lub miejsce prowadzenia działalności w obszarze właściwości sądu, dla którego pragnie wykonywać tłumaczenia);

- tylko dla lekarzy bez specjalizacji: dyplom ukończenia studiów i suplement do dyplomu;

- formularz autocertyfikacji (autocertificazione, deklaracja zgodności) dostępny w Biurze CTU zgodnie z art. 1 i kolejnymi Ustawy z dnia 15 maja 1997 r. Nr 127 (Regolamento di attuazione degli articoli 1, 2 e 3 della legge 15 maggio 1997, $n .127$, in materia di semplificazione delle certificazioni amministrative), na podstawie aktualnego dokumentu tożsamości; do pobrania i wypełnienia w dniu złożenia wniosku, w obecności urzędnika. W przypadku nieskorzystania $\mathrm{z}$ autocertyfikacji kandydat zobowiązany jest przedstawić akt urodzenia (niewymagający opłaty skarbowej), zaświadczenie o miejscu zamieszkania (wymagające opłaty skarbowej) oraz zaświadczenia z samorządu zawodowego (wymagające opłaty skarbowej);

- CV wraz z posiadanymi dyplomami oraz dokumentami świadczącymi o rzeczywistym przebiegu doświadczenia zawodowego i specjalizacji technicznej kandydata (kserokopia), np. faktury, umowy, współprace, publikacje itd.;

- zaświadczenie potwierdzające uiszczenie rządowej opłaty licencyjnej w wysokości 168 euro na konto pocztowe nr 8003, należące do Ufficio Registro Tasse di Roma, Concessioni Governative; należy skorzystać $\mathrm{z}$ odpowiednich formularzy dostępnych w urzędach pocztowych i na odwrocie wskazać tytuł zapłaty; płatność może być również dokonana zaraz po zakończeniu wpisu do rejestru;

- tylko dla tłumaczy: dyplom ukończenia studiów lub szkoły dla tłumaczy Scuola Interpreti e Traduttori wraz z opłatą skarbową; dla ob-

${ }^{15}$ Dla przykładu wybrano procedurę wpisu do rejestru w Biurze CTU w Rzymie. 
cokrajowców konieczne jest zaświadczenie potwierdzające znajomość języka włoskiego wraz z opłatą skarbową.

Nie są brane pod uwagę wnioski złożone przez kandydatów, którzy dołączyli do samorządu zawodowego w okresie krótszym niż 5 lat.

Zgodnie $\mathrm{z}$ art. 4 regulaminu Biura CTU posiadanie szczególnych kompetencji będzie oceniane przez przypisanie punktacji do dokumentacji przedłożonej przez kandydata zgodnie z następującymi kryteriami:

- udokumentowane wykonywanie zadań szczególnie ważnych: od 2 do 3 punktów za każde z nich;

- publikacje monografii dotyczących obszarów specjalizacji, dla których wymagana jest rejestracja: 3 punkty za każdą z nich;

- publikacje krótkich esejów, artykułów, notatek dotyczących obszarów specjalizacji, dla których wymagana jest rejestracja: od 0,5 do 1 punktu dla każdego z nich;

- udokumentowanie przebiegu nieprzerwanej działalności zawodowej: 5 punktów za każdy rok pracy.

Zakłada się, że szczególne kompetencje (specifiche competenze) posiadają kandydaci, którzy zgodnie z kryteriami określonymi powyżej zdobywają nie mniej niż 30 punktów. Czas oczekiwania na rozpatrzenie podań wynosi około trzech miesięcy. Osoby ubiegające się o wpis do rejestru powinny jednak uwzględnić fakt, że zanim zostanie im przydzielone zlecenie, czas oczekiwania może wydłużyć się do kilku miesięcy, a w najgorszym wypadku nawet do kilku lat. Spowodowane jest to tym, że włoscy sędziowie, słusznie lub nie, preferują powierzać pracę profesjonalnym tłumaczom, z którymi już wcześniej pracowali, ustanawiając tym samym relacje współpracy i zaufania.

We Włoszech nie istnieje jednak reguła, która określałaby osobę uprawnioną do poświadczania tłumaczeń. Niektóre sądy wymagają przedłożenia wielu dokumentów (dyplomy, zaświadczenie nadania numeru identyfikacji podatkowej NIP lub ewentualny wpis do Izby Handlowej), wydłużając w ten sposób cały proces, który prowadzi do wpisu do rejestru tłumaczy uprawnionych do składania przysięgi. Inne sądy nie wymagają tychże dokumentów i nie weryfikują nawet, czy dany tłumacz włada językami roboczymi, oraz nie wpisują go do rejestru. Wielu tłumaczy we Włoszech traktuje wpisanie na listę sądową jedynie jako zaszczytny tytul. $\mathrm{Z}$ zawodowego punktu widzenia rzeczywiście zawsze budzi to pewien szacunek, ale w rzeczywistości, oprócz niektórych przypadków, poświadczanie nie jest głównym i ciągłym źródłem dobrze płatnej pracy. Co więcej, wymaga dużej odpowiedzialności. Nie można zapominać, że figurowanie na liście CTU może oznaczać częste powołania do procesów lub przesłuchań przeciwko cudzoziemcom. Stawki są bardzo 
niskie, a w niektórych przypadkach nie można odmówić. Trzeba pamiętać, że jeżeli tłumacz popełni błąd w tłumaczeniu, które składał pod przysięgą lub oświadczał zgodność w celach sądowych, poniesie surowe konsekwencje przewidziane w przypadku fałszywych poświadczeń.

Konkludując, należy stwierdzić, że tłumaczenie przysięgłe we Włoszech może być wykonywane przez każdą osobę, która pod przysięgą przyjmuje za nie odpowiedzialność. Obecnie określenie „tłumacz przysięgły”, zresztą niewłaściwie używane, odnosi się do tłumacza, który - po spełnieniu warunków, o których wcześniej była mowa w niniejszym artykule - został wpisany do rejestru biegłych i doradców technicznych danego sądu (CTU). Jednakże figurowanie w takim rejestrze nie gwarantuje jakości tłumaczenia. Również osoba, która nie jest wpisana do rejestru danego sądu, ale złożyła przysięgę, może określać się mianem „tłumacza przysięgłego”. W rzeczywistości każdy sąd ma dwa wzory przysięgi zarówno dla tłumaczy figurujących w rejestrze sądu, jak i dla tych, których nazwiska w nim nie widnieją.

\section{Literatura}

Alibrandi, L., Corso, P., (red.), 2013, Codice penale e di procedura penale e leggi complementari, Piacenza.

Biernacka-Licznar, K., 2011, „Instytucja tłumacza przysięgłego w Polsce i we Włoszech. Kształcenie tłumaczy przysięgłych na studiach podyplomowych w Polsce", [w:] Nauczanie języka włoskiego na polskich uczelniach: doświadczenia i perspektywy rozwoju, seria Italica Wratislaviensia II, K. Biernacka-Licznar, J. Łukaszewicz (red.), Toruń, s. 165-182.

Calamandrei, P., 1943, Istituzioni di diritto processuale civile secondo il nuovo codice, Padova.

Drago, M. (a cura di), 2013, Codice civile e di procedura civile, Milano.

Kubacki, A., 2012, Tłumaczenie poświadczone. Status, kształcenie, warsztat i odpowiedzialność tłumacza przysiegłego, Warszawa.

\section{Akty prawne}

Ustawa z dnia 25 listopada 2004 r. o zawodzie tłumacza przysięgłego (Dz.U. Nr 273, poz. 2702 z późn. zm.).

Rozporządzenie Ministra Sprawiedliwości z dnia 24 stycznia 2005 r. w sprawie szczegółowego sposobu przeprowadzania egzaminu na tłumacza przysięgłego (Dz.U. Nr 15, poz. 129).

Rozporządzenie Ministra Sprawiedliwości z dnia 9 listopada 2010 r. w sprawie stażu adaptacyjnego i testu umiejętności w toku postępowania 
o uznanie kwalifikacji do wykonywania zawodu tłumacza przysięgłego (Dz.U. Nr 218, poz. 1441).

Ustawa z dnia 25 marca 2011 r. o ograniczaniu barier administracyjnych dla obywateli i przedsiębiorców (Dz.U. Nr 106, poz. 622 z późn. zm.).

\section{Źródła internetowe}

http://www.tlumaczeniaprawnicze.com.pl/2011/06/08/zmiany-w-ustawie-ozawodzie-tlumacza-przysieglego/ (dostęp: 7 grudnia 2013 r.). http://www.professionisti.it/frontend/articolo/1160/Come-diventaretraduttore-giurato-per-il-Tribunale (dostęp: 7 grudnia 2013 r.). http://www.e-schooloftranslation.org/professione-traduttore/traduzioni-giurate\#sthash.RqYVKW0J.dpuf (dostęp: 7 grudnia 2013 r.). http://www.mondolavoro.it/blog/il-traduttore-come-farlo-in-tribunale-e-dintorni/ (dostęp: 7 grudnia 2013 r.). http://www.ferrotraduzioni.it (dostęp: 7 grudnia 2013 r.). http://www.aniti.it/peritigiurati/VADEMECUM.pdf (dostęp: 7 grudnia 2013 r.). http://glottovolante.blogspot.com/2011/11/traduttori-registrati-presso-la-camera.html (dostęp: 7 grudnia 2013 r.).

http://www.proz.com/forum/italian/11943-come_diventare_traduttore_giurato.html (dostęp: 7 grudnia 2013 r.).

\section{Taking the long way: from Italy to Poland. Practical aspects of the profession of the sworn translator in Italy and the procedure for the certification of his or her qualifications in Poland}

\section{Summary}

In contrast to many other countries, in Italy there is no federal or state licencing or certification for translators. Some credentials are available to translators working in some language pairs in this country, but they do not carry the same weight - on the market or in the translation community - as federal licencing or certification in other countries, such as Poland. The aim of this paper is to describe the bureaucratic process a translator must accomplish to become a sworn translator in Italy. The article will also illustrate the course which an Italian sworn translator should undertake to have their qualifications legalised in Poland, a country where the state examination for sworn translators is obligatory.

Keywords: sworn translator, professional qualifications, translator's status

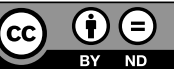

